\title{
Walking into Darkness
}

The Experience of Spinal Cord Injury 


\section{WALKING INTO DARKNESS}

\section{The Experience of Spinal Cord Injury}

\section{Oliver*, G. Zarb*, J. Silvert, M. Moore* and V. Salisbury ${ }^{*}$}

*School of Education Studies, Thames Polytechnic, London and

tThe National Spinal Injuries Centre, Stoke Mandeville Hospital, Aylesbury, Bucks.

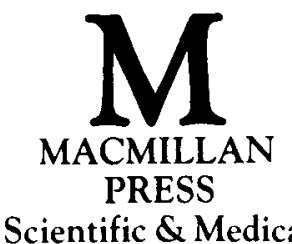


(C) The Authors 1988

All rights reserved. No reproduction, copy or transmission of this publication may be made without written permission.

No paragraph of this publication may be reproduced, copied or transmitted save with written permission or in accordance with the provisions of the Copyright Act 1956 (as amended), or under the terms of any licence permitting limited copying issued by the Copyright Licensing Agency, 33-4 Alfred Place, London WC1E 7DP.

Any person who does any unauthorised act in relation to this publication may be liable to criminal prosecution and civil claims for damages.

First published 1988

Published by

THE MACMILLAN PRESS LTD

Houndmills, Basingstoke, Hampshire RG21 2XS

and London

Companies and representatives

throughout the world

Typesetting by Footnote Graphics, Warminster, Wilts.

British Library Cataloguing in Publication Data

Walking into darkness.

1. Spinal cord injury victims. Rehabilitation

I. Oliver, $\mathrm{M}$.

$613.9^{\prime} 6^{\prime} 08808166$

ISBN 978-0-333-44361-3 ISBN 978-1-349-19451-3 (eBook)

DOI 10.1007/978-1-349-19451-3 


\section{Contents}

$\begin{array}{ll}\text { Preface } & \text { ix }\end{array}$

Acknowledgements xiii

$\begin{array}{lll}\text { Chapter } 1 & \text { Spinal Cord Injury in Context } & 1\end{array}$

History 1

Treatment and rehabilitation 3

Statutory provision $\quad 5$

Changing ideas, changing practices 6

$\begin{array}{lll}\text { Chapter } 2 & \text { The Present Study } & 7\end{array}$

Introduction $\quad 7$

Review of the literature $\quad 8$

Conceptual framework 11

Characteristics of the people interviewed 13

Conclusions 18

Chapter 3 The Medical Consequences of Spinal Injury 19

Introduction 19

Experiences at receiving hospitals 20

Transfer to the spinal unit 21

Discharge into the community 26

Conclusions $\quad 32$

Chapter 4 Personal and Family Responses to Spinal Cord

Injury $\quad 34$

Introduction 34

Factors affecting personal responses $\quad 35$

Extent of impairment and personal responses $\quad 38$

Personal responses at the time of injury 39

Personal responses on discharge from hospital 42

Personal responses over time 45

Family and personal relationships $\quad 47$

Conclusions $\quad 54$ 
Chapter 5 Leisure, Social Life and Mobility in the

Community

Introduction

Leisure time and activities $\quad 56$

$\begin{array}{ll}\text { Social life } & 61\end{array}$

Personal mobility and wheelchair use $\quad 65$

Private transport $\quad 66$

The implications of car ownership for social and leisure activities $\quad 66$

Public transport $\quad 69$

Conclusions $\quad 69$

$\begin{array}{lll}\text { Chapter } 6 & \text { Perceptions of Medical and Social Services } & \mathbf{7 2}\end{array}$

$\begin{array}{ll}\text { Introduction } & 72\end{array}$

Counselling and family support $\quad 74$

$\begin{array}{ll}\text { Hospital social work service } & 77\end{array}$

Physiotherapy and occupational therapy $\quad 79$

General practitioner service $\quad 80$

District nursing service $\quad 82$

Social services and social work support $\quad 83$

$\begin{array}{ll}\text { The role of voluntary services } & 87\end{array}$

$\begin{array}{ll}\text { Conclusions } & 89\end{array}$

Chapter 7 Housing and Accommodation 91

Introduction $\quad 91$

Housing circumstances on discharge $\quad 92$

Housing from a career perspective 94

Current housing circumstances $\quad 98$

$\begin{array}{lr}\text { Conclusions } & 102\end{array}$

Chapter $8 \quad$ Significant Living with a Spinal Injury 103

Introduction $\quad 103$

Employment situation at the time of injury $\quad 104$

Employment situation on discharge 104

Returning to education 108

Occupation at the time of interview 110

Unemployment $\quad 112$

Retirement $\quad 114$

$\begin{array}{ll}\text { Conclusions } & 114\end{array}$

Chapter 9 The Financial Consequences of Spinal Injury 116 Introduction 116

Financial aspects of the disability career $\quad 117$

$\begin{array}{ll}\text { Living on benefits } & 119\end{array}$ 
Obtaining legal compensation $\quad 121$

Conclusions

Chapter 10 Conclusions: What Kind of Life? 127

Introduction $\quad 127$

The spinal injuries service-from accident to grave?

Better co-ordination of existing services 128

$\begin{array}{ll}\text { Changes at NSIC } & 129\end{array}$

Bringing the family in $\quad 130$

Life is for living 131

A place to live 131

A good and useful life $\quad 132$

Money makes a difference 133

Social adjustment-a continuous and reciprocal process

Life expectancy or expectation of life? 134

References

Index 


\section{Preface}

For many years, the onset of disability has been viewed as a personal tragedy, and consequently the disabled person has been seen as a victim of such an unfortunate happening. Spinal cord injury has often been seen in such terms: the sudden nature of its occurrence-as the result of a road accident, a fall or a sporting injury-rendering someone who was previously fully fit and well, completely paralysed. The physical consequences of such a happening are best described in the words of Sir Ludwig Guttmann, pioneer in the development of a spinal injury service in the United Kingdom:

It must be remembered that the spinal cord, that big nerve trunk within the vertebral column, is one of the most important organs in animals and man. For it is the main mediator of all impulses from and to the brain. For instance, any volitional isolated muscle movement initiated from the brain is only possible if the spinal cord is intact, and vice versa-all forms of sensory impulses originating from the skin, muscles, joints and internal organs have to travel through the spinal cord to be consciously appreciated. Moreover, in addition to these vital functions, the cord contains in itself nerve centres for controlling bladder, bowel, sexual and respiratory functions.

Therefore, if the spinal cord is severed or crushed-by a knife, bullet, vascular catastrophe (thrombosis) or a fracture of the spine at any levelthis immediately results in a paralysis below the level of the injury, with loss of most essential functions. This involves all voluntary motor functions, appreciation of all forms of sensation, and results in loss of posture and control of bladder and bowels. Sexual function in men is abolished. Women lose sexual sensation but can have intercourse and still conceive. The higher up the spine the level of the injury the more parts of the body are cut off. In injuries of the cervical cord, the respiratory function as well as the blood circulation are greatly impaired, especially in very high cervical lesions, the involvement of the blood circulation leading also to a reduction of the tone of all tissues, especially skin and muscles. This in turn results in a lowering of their resistance to pressure, which is one of the most important causes of the development of pressure sores. All forms of sensation are cut off and the patient does not feel the 
discomfort of pressure, such as non-paralysed people do in the form, let us say, of pins and needles.

The victims of war, road, industrial and sporting accidents did not establish a social problem in the past, as their life expectancy was very short, two to three years at the utmost as a rule. Complications such as sepsis from ascending infection of the bladder into the kidneys, and pressure sores, were considered inevitable. Therefore, any attempt to restore such a person to his or her former social activities seemed to be out of the question, and the view generally held was the sooner they died the better for all concerned.

(quoted in Goodman, 1986:96-7)

Given this description, it is not surprising that spinal cord injury is seen as a catastrophic event in someone's life. However, largely as a result of the work of Sir Ludwig Guttmann at Stoke Mandeville Hospital, attitudes to recovery and rehabilitation, and a new approach to spinal cord injury, emerged:

The basic principle of this new philosophy was to provide a comprehensive paraplegia and tetraplegia service to rescue these men, women and children from the human scrapheap and return most of them, in spite of permanent, profound disability-by clinical measures and psychological readjustment-to a life worth living, as useful and respected citizens in the community.

(quoted in Goodman, 1986:101)

Partly as a result of this new approach, many people with spinal cord injury emerged from Stoke Mandeville, and later other hospitals, keen and eager to rebuild their lives or continue their existing ones with the least possible disruption. Not all, of course, made it, but many did and reappeared in society, working, marrying, enjoying a whole range of leisure pursuits and sporting activities, thereby challenging the stereotype of spinal cord injury as a personal tragedy.

The purpose of this book, therefore, is to describe the lives of people with spinal cord injury: to look at what happened to them at the time of their injury, on discharge from the spinal unit and at the time of the interview. Seventy-seven male ex-patients from Stoke Mandeville who had been disabled for between 2 and 15 years were traced and interviewed. The material from the interviews is presented in chronological order, tracing the 'disability career' of those interviewed.

This is not the first study to use the idea of a 'disability career' as a means of providing a chronological or temporal ordering of the data to be presented (Goffman, 1961; Safilios-Rothschild, 1970; Blaxter, 1980). Carver sets out the rationale for such an approach: 
A career in disability refers to the course or progress through life of any disabled person insofar as he encounters problems or handicapping conditions related in any way to his disabilities. A person's progress may be affected ... in practical ways and/or in the ways he thinks about himself or others. This concept of career is a broadly comprehensive one and implies that the individual is actively and repeatedly involved in the definition of his own problems and in the search for solutions, and, like any other career, it will comprise a succession of interactions with his environment, both physical and social.

(Carver, 1982:90)

These interactions, at the points in time already mentioned, are described in the words of the people with spinal injuries themselves, giving a sense of authenticity to the disability career.

The first chapter provides a brief history of the medical treatment and rehabilitation of people with a spinal injury, along with an outline of the medical consequences of such an injury and a description of the kinds of treatment facilities available in the United Kingdom. This discussion is located within the context of changing ideas of what are appropriate services for people with a spinal injury and historical changes in the patterns of community support. The second chapter then provides a conceptual framework for the study, seeing spinal cord injury as a 'significant life event' rather than a personal tragedy, and the operationalisation of the concept of social adjustment is also discussed. A short account of the development of the study is provided, together with a description of the methods used to collect the data. Finally, a brief description of some of the characteristics of the people interviewed is presented.

The next three chapters utilise the concept of the career. Chapter 3 focuses on the medical consequences of spinal injury, looking at the nature of the accident, immediate post-accident treatment at both general and specialist hospitals, the rehabilitation process and the medical problems that may arise after discharge and for the rest of the person's life. Chapter 4 then moves away from the immediate medical and physical impact of spinal injury, and focuses on the impact on the injured person and his family. The concept of social adjustment is crucial here, and it is suggested that personal and family responses to spinal injury can only be understood in the light of a whole range of personal, social and economic factors, and not simply as a function of the extent of residual disability. Chapter 5 then broadens out the discussion and looks at the effects that spinal injury has on interpersonal relationships, and the restrictions that it may create for leisure and the pursuit of various hobbies and interests, as well as examining the issues of personal mobility and public transport.

Social adjustment and a successful career in disability are not, 
however, solely dependent on medical and interpersonal factors: a range of external factors, such as the availability of suitable housing, the prospects of keeping or finding a job and the kind of income support that is available, are also critical. Chapter 6 is pivotal in relation to these issues, for it looks at the roles of various professionals, both within the hospital and in the community. It suggests that while these professionals should provide access to the range of support services, information and benefits available to people with a spinal injury, in practice these roles are inadequately fulfilled.

The next three chapters, therefore, look at the services available. Returning to the concept of disability career, Chapter 7 examines the range of accommodation available, the process of adapting existing properties for someone confined to a wheelchair, and the issue of personal choice about where to live and, indeed, with whom to live. Chapter 8 discusses the effects that spinal injury has on the prospects of keeping an existing job or finding an alternative one, on the capacities and capabilities of those so injured, and on the desire, or otherwise, to resume work. Chapter 9 then describes the financial circumstances of our interviewees and their families, the nature of financial hardships that some of them suffer, and the whole issue of compensation and disability income.

The final chapter then attempts to pull together the many themes that have been raised throughout the book. It summarises the key issues that have arisen; it considers and suggests improvements in the planning and delivery of services, both hospital- and community-based, and it argues that there is urgent need for action by all concerned if the 'disability career' of those with a spinal injury is to be significantly improved.

London and Aylesbury, $1988 \quad$ M. O.

G. Z.

J. S.

M. M.

V.S. 


\section{Acknowledgements}

We are grateful to the King Edward's Hospital Fund for London and the Jules Thorn Trust, who funded the research on which this book is based. The Spinal Injuries Association and the National Spinal Injuries Centre at Stoke Mandeville Hospital provided additional funds, and we are also grateful for their encouragement and support.

Without the help of two people in particular, this book might never have seen the light of day. Gill Creek was responsible for the coding and analysis of our statistical data and, hence, for giving our work a coherence it might not otherwise have had. Cathy Lewington typed the manuscript with such speed and efficiency that she was able to keep us supplied with tea when we needed it most, and it is thanks to her that the manuscript was not as late as it would otherwise have been.

Most of all, we owe an enormous debt of gratitude to those people with spinal injuries who allowed us to intrude on their lives and invade their privacy. Without them, there would have been no book, although, of course, any shortcomings in the final product are ours, not theirs. 